collective bargaining do not demand that the property rights of individual union members be sacrificed to the extent which may occur under the rules accepted by the courts. A faith-breaking parent should not be allowed to claim the local funds by virtue of forfeiture provisions contained in the charter; nor should a few self-seeking individuals, by remaining in the local, be able to acquire title to the entire property through the minimum membership requirements in the charter. ${ }^{41}$

Where the parent has failed to carry out its obligations or where the twofold contract contains no specific provision for disposition of local funds on a majority secession, the courts should impound the funds until the Board has affirmed the status of the existing bargaining agent or certified a new one. It should then recognize as the "original" local that group which is certified by the Board and should grant them the local funds. ${ }^{42}$ In this manner the courts can strengthen the union which will represent the workers in future bargaining with management.

\title{
"OBJECTIVITY" IN CIVIL SERVICE ORAL EXAMINATIONS"
}

INTEGRITY of public administration requires that the appointment and promotion of personnel be based upon relative merit and fitness. ${ }^{1}$ Accord-

41. Though some courts have said that they were not concerned with the question as to wheher the local was justified in seceding, see Suffidge v. O'Grady, 84 N.Y.S.2d 211, 214 (1948), others have indicated that they took into consideration the question whether the parent had deviated from the purposes set forth in the two-fold contract. Sce State Council v. National Council, 71 N.J.Eq. 433, 465, 64 Atl. 561, 573 (Cl. 1906) (where the parent in violation of the charter inserted an "insurance clause" therein, the court said that it might perhaps have been sufficient grounds in itself to permit a withdrawal by the majority.)

42. Where a local is comprised of workers from more than one plant, a secession movement may be followed by certification of the loyal group in one plant and the seceders in another. In that rare event the soundest policy would be to divide the funds among the groups certified in each plant, adopting as the basis of division the total loeal membership in each plant prior to the secession.

If neither the seceding majority nor the loyal minority is selected as the collective bargaining agent the court should give the funds to the seceding majority both where the parent has not been faithful to the two-fold contract, and where there is no express provision regarding disposition of funds on secession.

Where the union concerned does not come under the jurisdiction of the National Labor Relations Board the courts should attempt to coordinate their policy with that of the state labor relations board.

* Almassy v. Los Angeles County Civil Service Commission, 89 Adv. Cal. App. 295, 200 P.2d 846 (1948), hearing granted, 33 Adv. Cal. Rep. No. 15, Mlin. p. 2, Cal. Sup. Ct., Feb. 17, 1949.

1. See Kuetn, Civil Service in Public Werfare 29-40 (1940); Proctrz, Prurctples of Public Personnel Adarrnistration 11-16 (1921). Sce Allen y. Mickinley, 18 Cal.2d 697, 705, 117 P.2d 342, 347 (1941). For the argument against a career public 
ingly, when positions in the civil service involve administrative duties or extensive personal contact, the statutory mandate of open competitive examinations ${ }^{2}$ is implemented by personal interviews. These oral examinations afford an appraisal of character and personality, ${ }^{3}$ thus supplementing written tests of mental proficiency.

An appreciation of the necessity for civil service oral examinations also compels recognition of their inherent shortcomings. ${ }^{4}$ If improperly supervised, they pave the way for patronage and discrimination. Aware of the potentialities for abuse, courts have attempted to establish safeguards for maintaining fair competition. ${ }^{5}$ A recent example is Almassy v. Los Angeles service, but rather favoring limited tenure and rotation in office, see Andrew Jackson's first annual message to Congress (1829), quoted in WiLArERding, Governasent BY Merur 18 (1935).

2. This requirement stems from the Civil Service (Pendleton) Act, 22 Star. 403 (1883), 5 U.S.C. $\$ 633(2)$ (1946), which set up the merit system in the federal government. For its early justification, see Jenckes, Civid. Service of the United States (1867); Shepard, The Competitive Test and the Civil Service of States and Cilics in ECONOMrC TRACTS XIV (1884).

A few states have constitutional provisions for open competitive examinations. Sce CaI. Const. Art. XXIV, $\$ 1$; Colo. Const. Art. XII, $\$ 13$; N. Y. Const. Art V, $\$ 6$; Oнro Const. Art XV, $\$ 10$. Usually, however, the requirement is found in statutes and charters. E.g., Minn. Stat. AnN. \$43.09(4) (1946); Cleveland Charter \$ 92 (b) (1924). An explicit declaration of intent is found in the ATLANTA CoDE $\$ 6-409$ (1942): "[T] ence, knowledge, skill, personality, physical fitness and other pertinent matters and may be written or oral." A limitation uniformly imposed is that "All examinations shall be impartial, and relate only to matters which will test the fitness of the persons examined for the service they wish to enter. No question shall relate to political or religious opina ions or affiliations, and no appointment shall be in any manner affected by such opinions or affiliations." DENvER CHARTER \$228 (1927).

For the selection process generally, see Feddana, A Personnet. Procram for tul: Federal Civil Service 116-8 (1931); Kingsley, Recruiting Applicants for tue PunLIC SERvICE (1942) (committee report submitted to Civil Service Assembly of the United States and Canada).

Although the great majority of civil service positions are competitive, certain classes, notably labor and those of a high-policy-making nature, are often exempted from this requirement. The trend, however, is toward a completely competitive systeln. Sce Exce. Order No. 7916, 3 FED. REG. 1526 (1938), extending the competitive classified civil service.

3. The "oral examination" herein discussed refers only to personality evaluation, as opposed to an oral test of knowledge.

For an excellent analysis of the problem of civil service oral examinations generally, see Ordway, Oral Tests in Public Personnet Selection (1943) (committee report submitted to Civil Service Assembly of the United States and Canada), hereinafter cited as Ordway's Report. Also see Kiern, Civil Service in Public Welfare 152-9 (1940); Mosher \& Kingsley, Public Personnel Administration 213-29 (1941); O’Brien \& Marengerg, Your Federai Civil Service 233-47 (1940).

4. See Comarission of Inguiry on Public Service Personnel, Mfinutes of EviDENCE 197, 410 (1935) ; Mosher \& KrngsLEY, op. cit. supra note 3, at 213; ORDWAY's REPORT, at 114-20. For the view that oral tests are used far beyond the point warranted by their value, see Elements of Public Adnsinistration 563-4 (Marx ed. 1946).

5. See notes 15 and 16 infra. 
County Civil Service Commission," where a California appellate court outlined its requirements for insuring "objectivity" in oral examinations. A candidate who had failed both the written and oral halves of a promotional examination for Senior Deputy Probation Officer brought suit challenging the over-all validity of the oral phase. ${ }^{7}$ The standard interview procedure used there consisted of questioning the candidate on the information contained in his application and rating him on education, experience and "personal fitness." ' Although a record of the examiners' comments and ratings

6. 89 Adv.Cal.App. 295, 200 P.2d \&46 (1948).

7. Almassy's main contention was that the Commission had no authority to include an oral evaluation of education, experience and personal fitness, because such was not within the contemplation of the Charter requirement of "competitive examinations." Brief for Appellants, p. 3, Almassy v. Los Angeles County Civil Service Commission, $\$ 9$ Adv.Cal.App. 295, 200 P.2d 846 (1948). Significantly, no charges of arbitrary, capricious or fraudulent conduct on the part of the Commission vere advanced. Neither vas there any indication that the candidate's ratings were at all unreasonable. With efficiency and seniority credits, and a "boost" obtained on appeal to the Commission, his final grades were only $61.64 \%$ and $64.45 \%$ (70\% is passing). Indicative of the character of this candidate was his answer to one of the questions on the written examination. $Q$ : "Present in outline form the points which should be covered in a forty-minute speech to a group of trained social workers on the contributing factors to juvenile delinquency." A: "Anyone who spent 'forty minutes' talking to a group of trained social workers on the subject of the 'factors contributing to jurenile delinquency' would be wastcing [sic] their time, as well as his own, unless he were a politician running for office." Respondent's Reply Brief, p. 3.

S. Each candidate was interviewed by two well-qualified examiners, who rated him, independently, on the following form:

Personal Fitness:

Physical Characteristics

a. Appearance

b. Voice and Speech

Intellectual Factors

c. Alertness

d. Judgment (Depth and maturity of thinking.)

e. Ability to express ideas

Emotional Factors

f. Poise (Emotional adjustment, stability.)

g. Social adaptability

(Ability to meet people, make social adjustment.)

Professional Development

h. Orientation in the field

(Knowledge of new trends and current problems.)

i. Interest in the job

Final Evaluation:

$$
\text { Poor } \overline{\text { Weak }}
$$
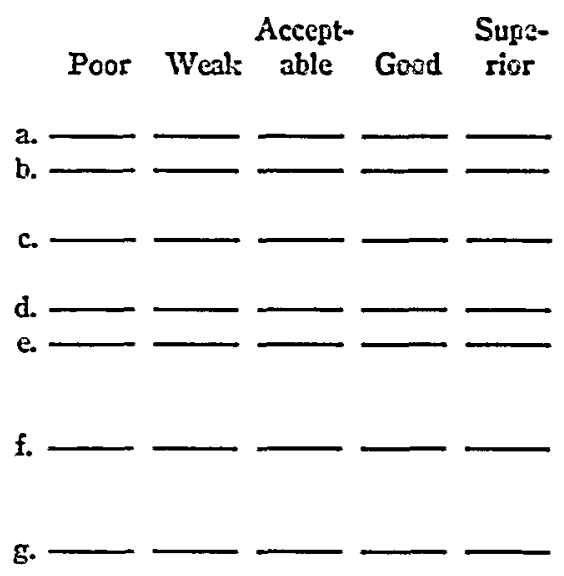

The qualitative entries were translated to numerical value according to a fixed formula 
was preserved, the court upheld Almassy's complaint on the ground that the record was inadequate for purposes of review. ${ }^{9}$ In addition, the competitive principle was held to be violated by the Commission's failure to provide "objective standards," exemplified by "definitions of the various 'personal fitness' factors" and "criteria for distinguishing between the various levels of evaluation." While the court did not prohibit oral examinations, it did, in effect, erect a presumption against the validity of the Commission's findings, thus condemning prevailing civil service methods of oral testing. ${ }^{10}$

In the review of a test which measures intangible factors of personality, the extent of the record is limited by practical considerations. Stenographic reproduction and notation of visible details afford only impersonal evi-

and the resultant grades of each examiner were averaged for a composite mark. For other sample rating forms, see ORDWAY'S REPORT, at 168-74.

9. This result, in view of the facts, see note 7 supra, seems most surprising. The trial court, in finding for the Commission, had taken very little evidence which would support the appellate court's decision. The Commission's "record," referred to by the court, consisted of an application blank, a General Qualifications Appraisal Record blank, and a blank form for a confidential report by the candidate's department head. No evidence appeared, in the trial court's proceedings, pertaining to appeal procedure employed by the Commission, to references and recommendations considered by the Commission, to instructions given to examiners, or to the appellant's original application or department head's report. No testimony of examiners or appellant concerning his ratings was presented. Nevertheless, the trial court was reversed and the entire examination and corresponding eligible lists promulgated thereon invalidated. Brief for City Attorneys of Los Angeles as Amici Curriae in Support of the Respondent's Petition for Hearing in the Supreme Court after Decision by the District Court of Appeal, pp. 20-2. Hearing grunted, Almassy v. Los Angeles County Civil Service Commission, 33 Adv. Cal. Rep. No. 15, Min. p. 2, Feb. 17, 1949.

With reference to the court's invalidation of the use of confidential department head reports, see generally Commission of Inguiry on Pubitc Service Personnet, Minutes of Evidence passinn; Probst, Service Ratings (1931) ; Probst, Measuring and Ratina Employee Value (1947). For a British viewpoint, see Royal Commission on the Civil. SERvice, Questions 1266, 1270, 1363 (1929-31).

10. The demand for "objective standards" would, at first glance, seem most justifiable. But personnel experts, constantly striving for a greater degree of objectivity in the selection process, have never been able to formulate standards sufficiently precise to satisiy the California court. See sources cited in note 3 supra. Likewise, the requirement of an "adequate record" is fulfilled in only a few jurisdictions. Communications to the YALE LAW JourNal from several state and local civil service commissions, including those of Illinois, Texas, Detroit and Los Angeles, indicate that the interview records they maintain arc similar to that in the Almassy case. On the other hand, the New York City Civil Service Commission employs stenotypists or phonographic recordings for their orals. Communication to the Yale Law Journal from S. H. Galston, Director, Examining Division, May 16, 1949. "Most of the civil service commissions in conducting oral examinations do not go much beyond requiring the oral examiners to keep an informal record of their comments and criticisms on which their ultimate ratings or appeals are based. In most instances the cost of transcribing oral examinations either through stenographic transcription or through recordings would be beyond their ability to finance." Communication to the Yale LAw Journal from H. Eliot Kaplan, former Executive Secretary, National Civil Service Reform League, May 5, 1949. 
dence, out of context; ${ }^{11}$ mere description of a candidate's remarks and his clothes fails to give any indication of "alertness" or "poise." Nothing short of sound motion pictures would satisfy the court's conception of a "record .. . showing basis of rating;" yet the resulting expense would be prohibitive. ${ }^{12}$ Clearly, then, the record alone cannot adequately testify to the validity of the ratings. And there is no compelling reason why it should, for its primary purpose is to expedite the privilege of appeal within the Commission. Here the record is not the sole basis for judgment. Confronted by the candidate, his examiners and the record, an expert Review Board can determine the soundness of ratings by comparing the testimony and evidence with its own observations. ${ }^{13}$ Reasonably, the extent and nature of the record to be used by the Review Board for this purpose are determinations which the Civil Service Commission should make. Then, if the ratings are litigated, the court should review in a manner similar to that of the Board rather than confine itself to weighing the bulk of a meaningless record.

The Almassy mandate for definitive gauges of "objectivity" stems from a literal interpretation of the New York ruling in Fink v. Finegan.14 In that leading case the court, invalidating an interviewing board's conclusion that the candidate "lacked force and executive ability," stated that "a test or examination, to be competitive, must employ an objective standard or measure." ${ }^{15}$ This declaration has become axiomatic in the few courts

11. "Isolated bits of evidence (gestures, expressions, reported incidents) which can be exactly specified in the record are likely not to be significant bases of our estimates of a candidate's qualifications. It is the composite picture which is revealing. . . . To set down the separate observations and then mechanically to rate them gives the appearance of objectivity and may satisfy a court, but has little promise, in my opinion, of achieving genuinely valuable appraisals of candidates. ... If we place the emphasis on trying to satisfy legal requirements for review, I fear we shall merely induce interviewers to record elaborate observations which serve as convenient excuses for their ratings-and worse, we may cause the interviewers to shy away from some of their conclusions . . . simply because they are unable conveniently to specify items of evidence which led to the final evaluation." Statement of Dr. Arthur W. Kornhauser, quoted in Orowny's REporr, at 131. But see Mosher \& KINGsLeY, op. cit. siprá note 3, at 221.

12. See OrDway's Report, at 128 .

13. Id. at $130,133-40$. The author notes, however, that, because of the difficulties attached to the maintenance of an adequate record, many jurisdictions make no provisions for appeal from oral test ratings. They feel that it only encourages futile argument; there can be presented no proof of error in the application of judgment to evidence which disappears when the candidate leaves the room. For a recommended appeal procedure, see 3 Ios Angeles Budget and Effictency Bureat, Repost of Administratte Sunier of the Civil Service Departaient 40-1, 77 (1947).

14. 270 N.Y. 356, 1 N.E.2d 462 (1936). See Levanthal, Administrative Law is Neso York Civil Service Litigation, 15 Fond. L. Rev. 62, 72 (1946).

15. Fink v. Finegan, 270 N.Y. 356, 1 N.E.2d 462 (1936) ; accord, Bridgman v. Kern, 257 App.Div. 420, 13 N.Y.S.2d 249 (1st Dep't 1939), aff'd, 2S2 N.Y. 375, 26 N.E.2d 299 (1940) (but see discussion of the case by Kaplan, Cizil Scricc-Recicu of Oral Eraminations, 5 Legal Notes on Local Gov't 286 (1940)).

But of. Lehman, J., in Sloat $v$ Board of Examiners, 274 N.Y. 367, 373, 9 N.E.2d 12, 
which have attempted to review civil service examinations. ${ }^{16}$ It derives from the assumption that a process involving extensive subjective judgment, vulnerable to conscious and unconscious prejudices, cannot be a true test of excellence. ${ }^{17}$ But this academic conception overlooks reality. Even on essay-type college and bar examinations, grades depend in large measure upon the mood and character of the scorers, and may vary over a wide range. ${ }^{18}$ The variations follow inevitably from the disparity of human minds. Even if bias were present, it would be undetectable when kept within reasonable bounds. Yet few would assert that the element of competition was not present. If "objective" connotes a modus operandi impersonal in nature and unconditioned by the mind, ${ }^{19}$ it is difficult to see how the oral examination can legally remain in the civil service selection process.

Continuation of competitive personal interviews for civil service employment is dependent upon a careful balancing of its values and its dangers. Where integration of mental and social attributes is essential to successful job performance, failure to consider relevant personality traits contravenes the merit principle. But if such an appraisal is allowed, it must not be enervated by constrained adherence to rigid standards of "objectivity." 20

15 (1937) : "The mandate of the Constitution for the ascertainment of merit and fitness, so far as practicable, by competitive examination, may not be transformed into an interdict against the examinations which are best adapted for the demonstration of fitness. It would be impossible to formulate a standard by which such qualities may be defincd or measured with entire objectivity. The law does not require the impossible or forbid the reasonable. ... Much must be left here to the judgment of the examiners. The test cannot be wholly objective and to the extent that it is subjective the result may depend as much upon the fitness of the examiners as upon the fitness of the candidate. That is a risk inherent in all systems of examination." Accord, Farrell v. Kern, 17 N.Y.S.2d 934 (Sup. Ct.1940). These cases have modified the Fink doctrine as to require a clear demonstration of arbitrariness.

16. In addition to the numerous New York cases, see, e.g., Wilson v. Los Angeles County Civil Service Commission, Civil No. 543,297, Los Angeles County Super. Ct., Sept. 23, 1948, p. 21; State ex rel. Kos v. Adamson, 226 Minn. 177, 185, 32 N.W.2d 281, 283 (1948). Thus far, these are the only states which have had to take a stand on the problem raised by the Fink case.

17. See Fink v. Finegan, 270 N.Y. 356, 361-3, 1 N.E.2d 462, 464-5 (1936).

18. For a careful summary of investigations on the comparison of marks alloted to examination papers by independent examiners and boards of examiners, together with a section on a viva voce examination, see HARTOG, AN ExAMINATION of ExaMINATION3 (1936). See also Klein, Civil Service in Public Welfare 167-8 (1940).

19. Webster's New International Dictionarx 545 (1947). It should be noted that if oral examinations ever achieved the dictionary definition of "objectivity," it might be at the expense of "reliability" and "validity." Yet these are equally important critcria for verifying data. If they are not satisfied, the effectiveness of oral examinations would be seriously impaired. See Pfiffner, Research Methods in Public Administuation 153-5 (1940).

20. See note 19 suprc. If, as the Almassy decision suggested, substantial uniformity of questions is a necessity, superficial evaluation will be engendered. Such standardization would not only facilitate "cramming" and memorization of answers, but would also hamper insight into personality by its lack of flexibility. 
Formulation of a precise, valid measure to distinguish between "acceptable poise" and "good poise" is clearly impossible. The evaluation thrives on the flexibility of the examiner's judgment and the wealth of his experience. ${ }^{21}$ Admittedly, the absence of a yardstick for reviewing these judgments opens the door to personal and political prejudice, and might destroy fair competition. But a realistic analysis indicates that corruption in civil service is not rampant, ${ }^{22}$ that scientific methods are employed, ${ }^{23}$ and that controls are adequate. ${ }^{24}$ Accordingly, due respect for the importance of oral examinations warrants recognition that the presence of subjectivity is less reprehensible than the consequences of inadequacy in selecting prospective public servants.

In the absence of palpable illegality, courts generally hesitate to upset administrative determinations and procedures in internal governmental operations. ${ }^{25}$ Yet, any court following the Almassy reasoning can find a lack of "objectivity" in existing oral examinations." Perhaps a de-emphasis

21. See sources cited in note 23 infra.

22. See Elevients of Public Adarinistratton 448-77 (Mfar: ed. 1946).

23. See BInghazr \& MIOoRE, How To InTERVIEw 127-39 (1941); Oroway's Rerors, at 86-109. A brief and interesting account of the training of esaminers by means of trial interviews, whereby common man-to-man standards of rating are adopted, is found in 44 U.S. Civil Sertice Commisston ANn. Rep. 37-12 (1927).

24. E. g., grading by two or more examiners, provisions for review within the Commission, resort to the courts in cases of fraud or caprice. In addition, the careful selcetion of interview boards should assure honest conduct of oral tests. See State Pensoninar Board of Alabaji, Miertr Systemr Handboor (Revised Rules) Rule VI, \$8 (1941); and sources cited in note 3 , supra.

25. E.g., Keim v. United States, 177 U.S. 290 (1900) (refusing to review dismissal of clerk by Secretary of the Interior for "inefficiency"); Friedman v. Schrellenbach, 159 F.2d 22 (App. D.C. 1946), cert. deried, 330 U.S. 838 (1947) (refusing to review discharge of War Manpower Commission division chief after a finding that reasonable doubt existed as to his loyalty); Levine v. Farley, 107 F.2d 186 (App. D.C. 1939), cert. deriicd, 308 U.S. 622 (1940) (refusing to review dismissal by Post Office Department for publishing statements "tending to bring the service into disrepute"). For the application of this principle to civil service tests, see Cowan v. Reavy, 283 N.Y. 232, 234, 23 N.E.2d 390 (1940) ; Maxwell v. Civil Service Commission, 169 Cal. 336, 339, 146 Pac. 871 (1915) ("They may decide a particular question wrong-but it is their question. Such boards are vested with a high discretion and its abuse must appear very clearly before the courts will interfere.")

26. See note 10 supra. But of. Snyder v. Finegan, N.I.Sup.Ct, SFecTerm, 1937, aff'd men., 253 App.Div. 707, 1 N.Y.S.2d 641 (1st Dep't 1937), aff'd mem. sub. nom3. Snyder v. Kern, 278 N.Y. 665, 16 N.E.2d 394 (1938). "It was developed at the trial that the ratings of the three commissioners on some of the factors differed as wide as the poles. On some factors such as exercise of good judgment, poise, etc. one commissioner rated Snyder as low as $40 \%$, while another commissioner rated him as high as $85 \%$. In spite of this, the Court nevertheless upheld the oral evamination as sufficiently compatitive and within the province of the Commission. ... If ever there was a case which, in $m y$ judgment, warranted the Court in setting aside the oral examination as lacking in competitive objectivity, it was the Snyder case ..." Communication to Andrev O. Porter, Deputy County Counsel in the Almassy case, from H. Eliot Kaplan, former Esceutive Secretary of the National Civil Service Reform League, February 23, 1949. 